\title{
Dynamic Spatial Modeling of Optimal Locations for Territorial Planning Ordering of the Industrial Waste in a Mining City ${ }^{+}$
}

\author{
Marcelo Pérez *, Rodrigo Estay and Víctor Encina \\ Department of Metallurgical Engineering and Materials, Federico Santa María Technical University, \\ Santiago 8940000, Chile; rodrigo.estayh@usm.cl (R.E.); victor.encina@usm.cl (V.E.) \\ * Correspondence: macelo.perezc@usm.cl; Tel.: +56-2-2303-7297 \\ + Presented at Environment, Green Technology and Engineering International Conference (EGTEIC 2018), \\ Caceres, Spain, 18-20 June 2018.
}

Published: 23 October 2018

\begin{abstract}
In mining, the decrease in the quality of grades has led to further deepening of the existing deposits, determining the existence of a greater quantity of waste, increasing the probability of contact between the waste and the environment, communities and productive soils. For this reason, we propose new logics to organize mining spaces, employing Multi-Criteria Evaluation techniques, risk assessment and the integration of spatial data into the Geographic Information System, with the purpose of determining the optimal locations of industrial waste deposit. Also, using cellular automata, we define a sustainable logistic plan for the dynamic distribution of waste, evaluating the interaction of a determined rhythm of waste production, with the variable dynamic of the wind. In conclusion, a new methodology of systematic vision is created for the planning and territorial ordering of future mining projects.
\end{abstract}

Keywords: GIS; Multi-Criteria Evaluation; Cellular Automata; sustainable mining; territorial ordering; optimal location of mining wastes

\section{Introduction}

During the last decade, one of the greatest challenges that mining activity has presented, is how this industry can be compatible with the global convention of sustainable development. In the mining sector, as well as academic and corporate circles, still has not achieved fully allaying the doubts and opinions in respect to whether the concept of sustainability is applicable or not to mining [1-3].

Is in this line where this investigation presents its key purpose and contribution, incorporating the study of the territorial ordering in the mining decision-making, for the planning of the proper uses of soil and the determination of optimal locations for its waste.

The study takes place in the IV Region of Coquimbo in Chile, a region which presents $50 \%$ of the Mining Environmental Liabilities (MEL) of the entire country and at the same time, possesses a similar percentage of untapped resources. The territory is analyzed under multiple geo-referential variables and integrated into Geographic Information System (GIS), utilizing Multi-Criteria Evaluation techniques (MCE), Analytical Hierarchy Process (AHP), and Cellular Automata (CA).

\section{Methodology}

\subsection{Optimal Locations in GIS-MCE-AHP}

The optimal locations stem from which in this investigation has been named Risk Index, which correspond to the cells $\left(1 \times 1 \mathrm{~km}^{2}\right)$ with the values of IR $<3.8$ or, equivalent, $\leq-0.5$ times standard 
deviations. The results are obtained from the MCE, which was performed considering the linear weighted sum method [4], which consists of multiplying the value of each criterion (geo-referenced data reclassified in values of vulnerability ranging from 1 to 5 , corresponding to the minimum or maximum vulnerability or probability respectively) by the global weight of each factor.

For the determination of the weights of the factors the Analytical Hierarchy Process was utilized proposed by Saaty (1980) [5].

Previously, twenty-two physical and human variables were proposed to determine the impact of the territory against the disposal of a massive mineral waste, where using the Fuzzy process, they have been normalized and standardized each one under different roles [6].

\subsection{Cellular Automatons}

We may define a cellular automatons as a discrete dynamic system formed by a combination of simple rules, which are idential within themselves, but combined are capable to demonstrate complex behavior. In the traditional use of CA, the state of each element, depends on the previous state of their neighboring elements, according to a combination of rules of transition [7]. In this research, we changed this definition of the behaviour of the CA, being that the state of the dump-cell (in production or not) will change if it affects a restricted cell (IR $\geq 3.8$ ), which can be contiguous or not, with particulate material.

The dynamics of the automaton responds to the following general rules: a time step of one hour, which is the resolution of the model; a height of the dump waste which will be growing according to the production rate, with a maximum value of $120 \mathrm{~m}$; a prioritization in the selection of the "next cell", considering the minimum distance from the origin of the mining to the cell of evaluation and, when the radius in which pollution may impact a cell with an $I R \geq 3.8$, the automata take another location, succesively repeating within the optimal possible options.

\subsection{Methodological Design}

The degrees of vulnerability for each factor were reclassified in values of 1 through 5 according to the level of probability of occurring or susceptibility. Later, each value is multiplied by the global weight obtained through the AHP for each class, obtaining a map of risk which is subsequently used as a basis for the development of cellular automata. The optimal locations defined by a risk index IR $<3.8$ are evaluated.

Subsequently, specific locations of open-pit mining are defined and its trapezoidal waste deposit, within each cell of the grid covering all the available area. The growth of these piles with the interaction of the wind, in different height intervals, provokes dispersal of fine material particles $(<10$ $\mu \mathrm{m})$ toward surrounding areas of the territory.

We use a power-law wind profile to estimate the horizontal wind speed, considering only a stable atmospheric condition. The minimum necessary wind velocity that we will consider for that the particle leaves the dump will be $5 \mathrm{~m} / \mathrm{s}$.

The reach radius, of the dispersal fine material particles, for the proposed mining dump site, was obtained considering the direction of winds predominant in the zone, its velocities, the terrain level and the depositional velocity of the particle $(1 \mathrm{~m} / \mathrm{h})$.

Then, the simulation will iterate in each possible cell, until the pollutant emitted by the waste dump fall in a cell with IR $\geq 3.8$ or a dump reached the maximum height of $120 \mathrm{~m}$.

We didn't consider the effects of the atmospheric boundary layer and its associated vertical winds, the variations in temperature or any other variation in meteorological variables.

\section{Results}

A systemic analysis of the territory was considered, under a previous scenario of the mining operation, with the goal of conducting a comparative analysis against the final result (Figure 1). The activity in the region presents multiple mining waste classified as environmental mining liabilities. 

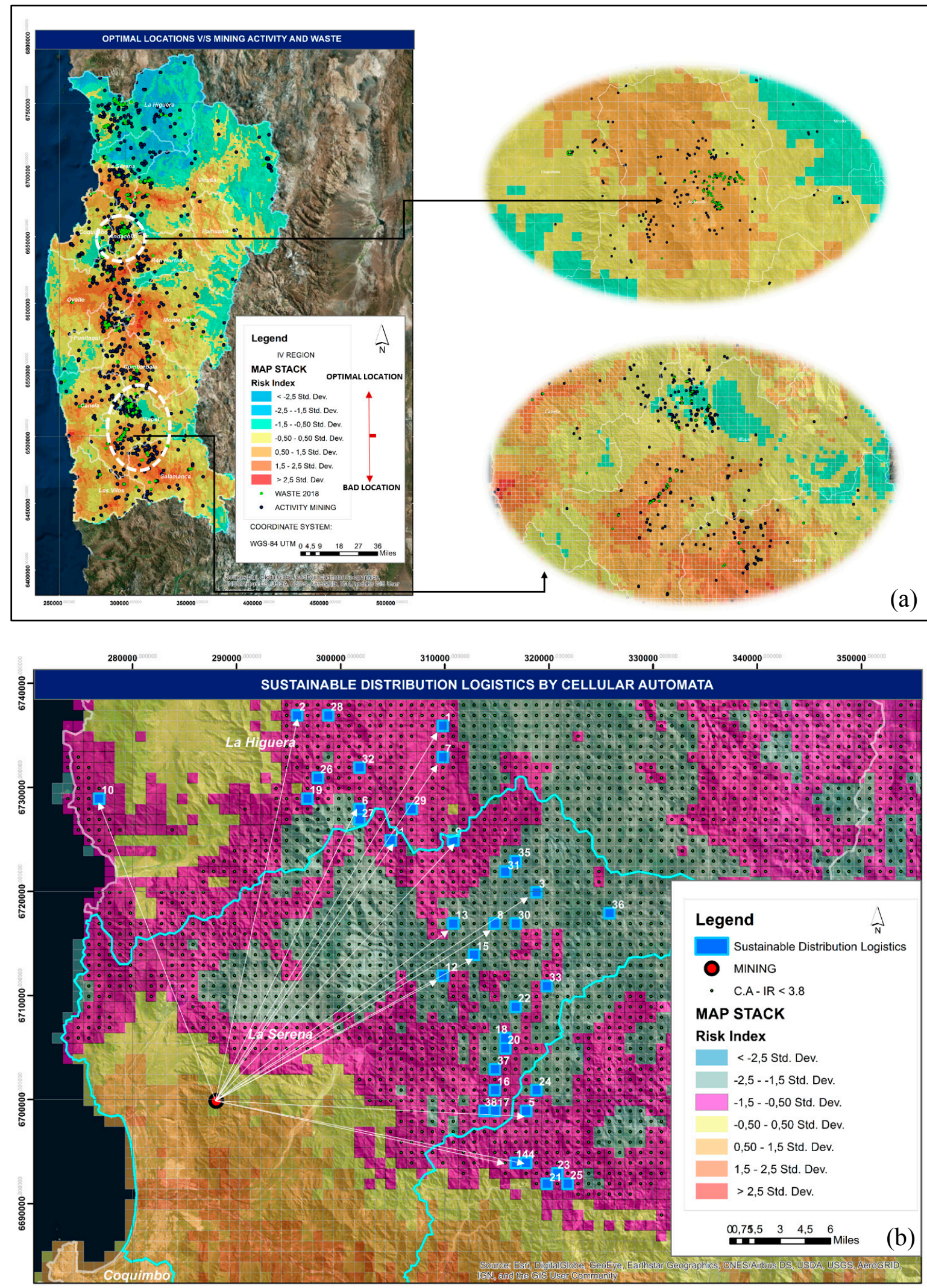

Figure 1. (a) Levels of compatibility and incompatibility that exists between the modeled scenario (before the mining activity) versus the present scenario with an operating mine. (b) Results from CA programming. The red point corresponds to the location of the mine, in magenta the risk border cells and the green cell are those with IR $<3.8$. Cells in blue are those selected as optimal location in increasing order of impact (increasing IR value, see Figure 2). 


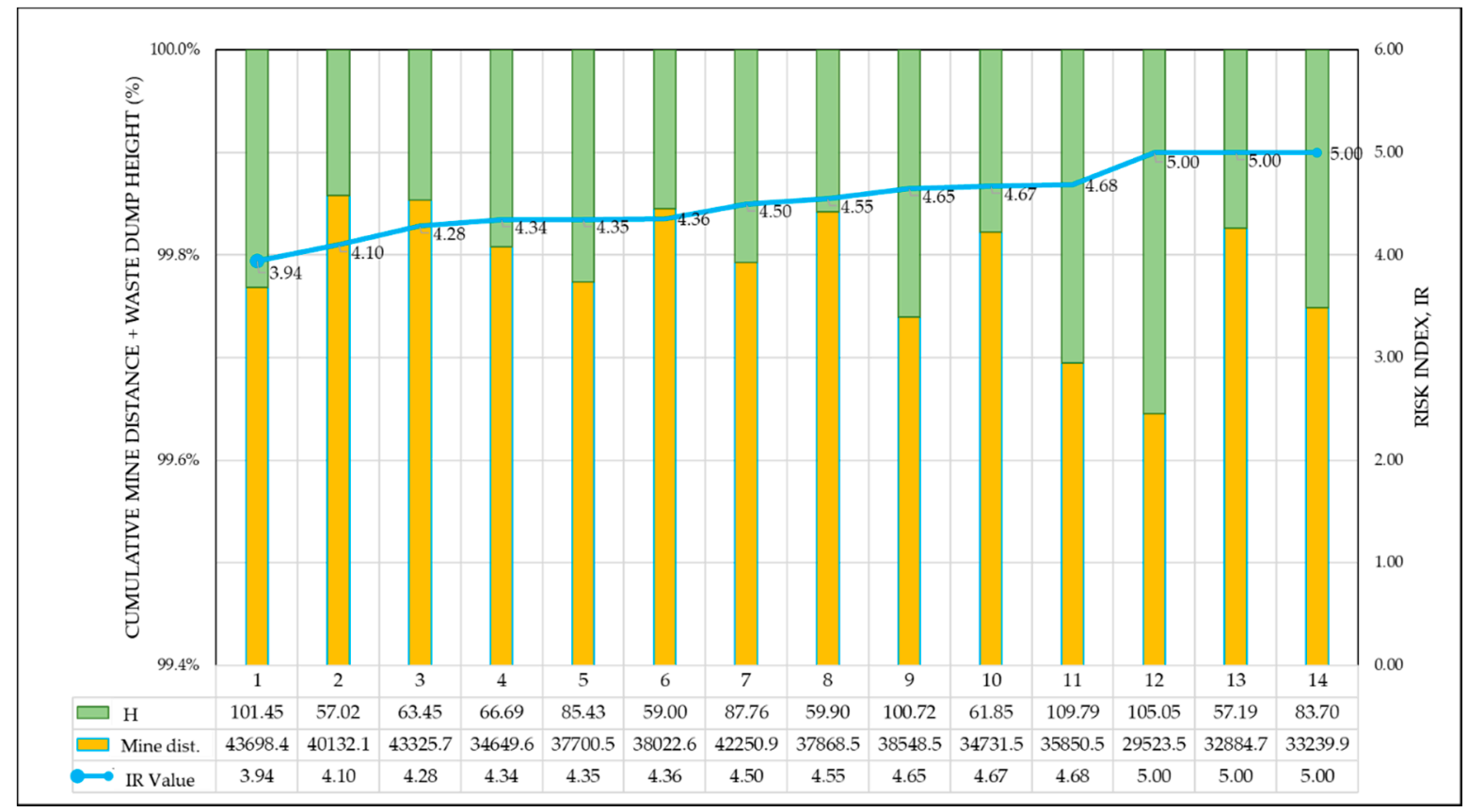

Figure 2. Distribution of the first 14 of 37 options, identifying the minimum impact value (minimum IR), maximum dump height reached and the distance mine-waste dump.

Thirty-seven cases where selected as optimal possibilities (Figure 1). The first case generates the minimum impact, according to the value of IR. Also, a good capacity of waste is achieved $(101,450,000$ $\mathrm{m}^{3}$ ) with a height of $101.45 \mathrm{~m}$, but at the expense of a larger distance between mine and the dump (Figure 2). Nevertheless, the alternative 12 presents a minimum distance mine-dump (which implies a lesser transport cost), a similar volume capacity $\left(105,000,000 \mathrm{~m}^{3}\right)$ but with a higher impact $(\mathrm{IR}=5.0)$. This level of volume is equivalent to 46 years of production of 10,000 ton of waste with density of 1.6 ton $/ \mathrm{m}^{3}$.

\section{Discussions and Conclusions}

The proposed methodology permits the construction of an efficient tool to make decisions about the use and management of massive mining waste, by determining optimal locations most efficient at the moment of planning a logistic of sustainable distribution.

This is a first approximation (and the best-case scenario) to a very complex problem in nature, where there are various parameters and criteria which can be calibrated in a more precise manner and variable which eventually could be included or measured with greater precision and level of update, which would make a more robust and exact model.

In general, the results pose various challenges, for the engineering sciences, against the development of technologically innovative methods. The innovations should point to technologies that mitigate the impact even more, contribute to the reduction of the quantity of waste produced, independent of the method of mining; encourage ways of reutilization of the waste for other purposes and find new methods to deposit and transport waste that are competitive in costs.

Finally, the investigation states the idea that, sustainable mining is a fact.

Author Contributions: M.P. developed a global proposal of the methodological design, integrating the science of land -use in mine planning, using GIS, EMC, AHP and CA methods; R.E. programmed in Matlab the CA method; V.E. defined the expert criteria considered in the mining process; M.P. and R.E. analyzed the results and wrote de paper.

Acknowledgments: The authors acknowledge to the Federico Santa María Technical University that financed the trip to the Conference through its Complementary Support Program for Research. 
Conflicts of Interest: The authors declare no conflict of interest. The founding sponsors had no role in the design of the study; in the collection, analyses, or interpretation of data; in the writing of the manuscript, and in the decision to publish the results.

\section{References}

1. United Nations. Report of the World Commission on Environment and Development, "Our Common Future"; United Nations: New York, NY, USA, 1987.

2. Wiertz, Jacques. Minería Sustentable? Opinion Column. Available online: http://ingenieria.uchile.cl/ noticias/109964/opinion-mineria-sustentable (accessed on 5 June 2018)

3. Echavarría, C. Transacciones complejas entre el potencial y lo viable. In Minería y Desarrollo Sustentable; Iniciativa de Investigación sobre Políticas Mineras (IIPM) del International Development Research Centre (IDRC): Ottawa, ON, Canada, 2004; Volume 3.

4. Encina, V.; Pérez, M. Modelo holístico de minería sustentable: Un paradigma para afrontar el cambio climático. In Proceedings of the XXXVII Congreso Nacional y XXII Internacional de Geografía: Geografía para un Desarrollo Humano Sustentable, Talca, Chile, 24-29 October 2016.

5. Barredo, B.J. Sistemas de Información Geográfica y Evaluación Multicriterio en la Ordenación del Territorio; RAMA Editorial: Madrid, Spain, 1996; 263p.

6. Saaty, T. The Analytical Hierarchy Process; Mc Graw Hill: New York, NY, USA, 1980.

7. Henríquez, C.; Qüense, J. Multi-criteria/Multi-Objective Evaluation Applied to Land Use/Cover in Chillán Watershed, 2010, FONDECYT Proyect. Available online: https://goo.gl/PW5WoV (accessed on 5 June 2018)

(C) 2018 by the authors. Licensee MDPI, Basel, Switzerland. This article is an open access article distributed under the terms and conditions of the Creative Commons Attribution (CC BY) license (http://creativecommons.org/licenses/by/4.0/). 